\title{
Growth Performance Evaluation of Leaf Characteristics of Rhizophora Racemosa Grown in amended Mangrove - Garden Soil
}

\author{
OJI, OO; AKONYE, LA; TANEE, FBG
}

\author{
Department of Plant Science \& Biotechnology, University of Port Harcourt, Port Harcourt, Rivers State Nigeria \\ Corresponding Author Email: Oj.korie@gmai.com,akony.love@uniport.edu.ng; loveakonye@yahoo.com franklin.tanee@uniport.edu.ng
}

\begin{abstract}
The present study investigated the effect of soil type on leaf characteristics of the Rhizophora racemosa. Matured propagules were grown for 75days on mangrove and garden soil amended with Saw dust (SD), Rice husk (RH), NPK and RH+ SD+NPK combination treatments at the Botanical Garden of the University of Port Harcourt. Leaf properties such as leaf area, Leaf dry weight, specific leaf area and leaf dry matter content was determined 75days after planting. The leaf area of Rhizophora racemosa were not significantly different from one another at $\mathrm{p}<0.05$ in the amended garden soils while in the amended mangrove soils there was significant difference. Result of leaf dry weight showed significant difference at $\mathrm{p}<0.05$ in both amended soil types. Maximum Specific Leaf Area of $157 \pm 31.7 \mathrm{~cm}^{2} \mathrm{~g}$ ${ }^{1}$ was observed in the garden soil amended with RH+ SD+NPK combination while the highest SLA of $143.7 \pm 19.3 \mathrm{~cm}^{2}$ $\mathrm{g}^{-1}$ was observed in the mangrove soil amended with SD. Leaf Dry Matter Content varied from $0.224 \pm 0.012 \mathrm{~g} \mathrm{~g}-1$ $0.271 \pm 0.013 \mathrm{~g} \mathrm{~g}-1$ across the various amendment in the mangrove soil while it ranged from $0.256 \pm 0.004-0.355 \pm$ $0.041 \mathrm{~g} \mathrm{~g}^{-1}$ ) for the garden soil. Result indicated that Rhizophora racemosa can be successfully raised in amended garden and mangrove soil, and this may provide valuable information for mangrove forest restoration in the Niger delta region.
\end{abstract}

\section{DOI: https://dx.doi.org/10.4314/jasem.v22i8.12}

Copyright: Copyright (C) 2018 Oji et al. This is an open access article distributed under the Creative Commons Attribution License (CCL), which permits unrestricted use, distribution, and reproduction in any medium, provided the original work is properly cited.

Dates: Received: 05 June 2018; Revised: 19 July: 2018; Accepted: 22 August 2018

Keywords: leaf area, leaf dry weight, leaf dry matter content; specific leaf area

Nigeria has the largest mangrove forest in Africa and the fifth largest in the world behind Indonesia, Australia, Brazil and Mexico (Daniel and Edward, 2013). The mangrove forest of Nigeria extends from Badagry in the West to Calabar in the East covering a total area of $10,000 \mathrm{~km} 2$ along the coast. The forests comprises principally only three families and six species namely: Rhizophoraceae (the red mangrove) with three major species:- Rhizophora racemosa, $R$. harrisonii and $R$. mangle. The species Rhizophora racemosa is the most abundant taking about $90 \%$ of the mangrove forests and occurs at the outer body of water. Avicenniaceae - (white mangrove) Avicennia Africana; Combretacea - Lagancularia racemosa and Conocarpus erectus. Another exotic plant that is found associated with the mangrove forest of Niger delta is Nypa fruticans (Nypa Palm) (NDES, 2000).

Mangrove provides many ecosystem services, such as support for local livelihoods through the provision of fuel, food and construction materials. It host a wide variety of biodiversity, providing habitats for fauna including aquatic and terrestrial insects, fish, crustacean, mammalian, amphibian, reptilian and avian species, Hogarth (1999). Mangroves have been found to sequester high amount of carbon comparable only to those of the dense Amazon forest, (Donato et al., 2011). This makes mangroves an important asset for carbon trading initiatives such as Reduced Emissions from Deforestation and Degradation (REDD+) in addition to their financial value in terms of the payments for ecosystem services (PES) that they support, (Lucas et al 2014.). Rhizophara racemosa is a major dominant species (NDES, 2005) and adorns the coastal areas of the Niger delta region (RPI, 1985) where it occurs in the intertidal zone with a wide range of hydrological conditions. Due to their unique location, mangroves are subject to fluctuations in freshwater as well as sea-level rise and salinity. Salinity has been held as a controlling factor that determines the development, growth and distribution of mangrove forests (Twilley and Chen, 1998). However, recent findings by Doyle (2003) have shown that their growth in the estuarine environment is due primarily to their adaptation traits and their poor competitive ability with other plants. Supporting the non-salinity precondition, (Doyle, 2003) has demonstrated that mangrove can survive, thrive and successfully regenerate given limited competition from other plants in freshwater systems thus concluding that it was actually the substrate and nutrient quality that play a 
much greater role than the factors of hydrology and salinity in determining mangrove growth and form.

Leaf weight and Leaf area basically are important factors in most ecophysiological studies in terrestrial ecosystems regarding their roles as light interceptors, sites of evapotranspiration and photosynthesis. Both are useful in quantifying primary production and competition among species respectively by physiologists and ecologist (Pandey and Singh, 2011). Also specific leaf area (SLA) and leaf dry matter content (LDMC) are both important indicators in plant ecology because they are connected to the various critical aspects of plant growth and survival (Akonye and Nwauzoma, 2003; Garnier et al.; 2001). Several studies have revealed their critical roles in explaining variations in potential growth rate and the ecological behaviour of plants (Diaz et al, 2004).

Given this, the present study focused on the possibility of raising R.racemosa propagule on other soil type outside the normal mangrove soil using different leaf characteristics as indicator of performance. It is expected that the result will open up other media of raising mangrove propagule for the revegetation of the mangrove ecosystem of the Niger delta which is fast disappearing due to several anthropogenic factors.

\section{MATERIALS AND METHOD}

Site description: The study was carried out at the Botanical Garden of the University of Port Harcourt. The area lies within the tropical rain forest ecological zone in southern region of Nigeria popularly referred to as the Niger delta. Uko and Tamunobereton-Ari (2013) has reported the meteorological characteristics of the study area. Monthly temperature during the dry season (November - February) ranged between 31.13 $-33.08^{\circ} \mathrm{C}$ with a mean of $31.97^{\circ} \mathrm{C}$ while during the rainy season (March - October), the temperature ranged $25.71-32.48^{\circ} \mathrm{C}$ with a mean of $29.095^{\circ} \mathrm{C}$. The area records a $2400 \mathrm{~mm}$ mean annual rainfall (Dike and Nwachukwu, 2003) which peaks during the months of July and September.

Experimental design: The experiment consists of two treatments [garden soil (GS) and mangrove soil (MS)] and each was subdivided into five subsets. The five subsets were numbered 1 to 5 for each treatment. Subset number 1 had no amendment and served as control GS or MS, number 2 was amended with Saw dust (SD), number 3 was amended with Rice husk (RH), number 4 amended with NPK (10:10:10) and lastly number 5 was amended with a combination of SD+RH+NPK . Each subset of a particular treatment was replicated six times and was made by filling $2.0 \mathrm{~kg}$ of mangrove and garden soil respectively in a polyethylene bag $(28 \mathrm{~cm} \times 20 \mathrm{~cm})$. Mangrove soil were collected from the intertidal zone of Ogbogoro estuarine waters $(535525.548 \mathrm{~N}, 270244.003 \mathrm{E}$ and $535498.008 \mathrm{~N}, 270306.874 \mathrm{E})$ where $R$. racemosa grows using hand trowel while garden soil was collected from botanical garden at approximately $5 \mathrm{~cm}$ deep. Debris and partially decomposed materials were carefully removed before soil collection. The soils were homogenized separately and potted into garden and mangrove soil respectively. Each of the polythene bag containing the prepared soil was amended with its assigned amendment. This was done by weighing $15 \mathrm{~g}$ of the relevant amendment in a balance (Labtech digital Balance BL20001) and subsequently mixed with the soil in the first $10 \mathrm{~cm}$ of the prepared soil types while in the combination amendment $5 \mathrm{~g}$ each of SD, $\mathrm{RH}$ and NPK was first weighed in a balance and mixed together first before applying onto the soil. The polythene bags containing the amended soil were laid out in a partially shaded plot, allowing for natural sunlight and rain to reach it and left for four days to allow for decomposition and thorough mixing with the soil material. Nevertheless, the polythene bags with the soil were watered once every two days with fresh tap water throughout the duration of the experiment ensuring that the soil remains wet. Matured propagules were assessed using colouration as described by Duke and Allen, (2006) and by touch (Cavalcanti, 2007). The propagules had a mean fresh weight of $25.884 \pm 1.42 \mathrm{~g}$ and a height of $33.345 \pm 1.48 \mathrm{~cm}$. On day five (5) post soil amendment, propagules of $R$. racemosa were planted in the prepared soil at $5 \mathrm{~cm}$ depth. Soil samples for physicochemical analysis were collected to a 5-cm depth from each polythene bag using a spartula. The samples were air-dried and passed through a 2-mm sieve. Soil $\mathrm{pH}$ and electrical conductivity (EC) were measured in a soil-water suspension (1:1 and 1:5 soil to water ratio, respectively electrometrically) using OAKTON

PH/Conductivity/TDS/Salinity/Temperature Multi parameter testr35 35425-00. Total Organic Matter was determined by loss on ignition method while Total organic carbon (TOC) was determined by calculation using total organic matter result applying the 'Van Bemmelen' factor (Nelson and Sommers, 1996). Total $\mathrm{N}$ was measured by the Kjeldahl (Wright and Westoby, 2003).

Measurement of leaf characteristics: After seventy five (75) post planting day, the plants were harvested from the potted bags and excess soil segments washed off from the roots with fresh tap water. Care was taken not to damage the roots of the plants. The harvested plants were separated into roots, stem and leaves. Leaf samples were immediately placed between wet papers, sealed in a plastic bag, labeled and placed in a dark 
container with ice. Transporting of samples to the laboratory was within 30minutes and the samples were subsequently placed in water in the dark at $5^{\circ} \mathrm{C}$ for 12 $\mathrm{h}$ after which the petiole was removed under water Garnier et al., (2001). This procedure ensured that the leaf samples fully rehydrated. After $12 \mathrm{~h}$ leaves were then dried with tissue paper to remove surface water and leaf area estimated. Leaf area was estimated by laying a sample of the rehydrated leaf to be measured on a $1-\mathrm{cm}$ grid graph paper and the outline traced and counted (Pandey and Singh, 2011). The number of square centimeters completely covered by the trace was counted and this gives the area of the leaf. There after the leaves of each plant were immediately weighed to determine their saturated fresh weight. Also the stem and roots of each plant were weighed separately on a digital Labtech digital balance, BL20001. The entire plant sample components were thereafter oven-dried at $60^{\circ} \mathrm{C}$ using Memmert oven for (48) hours until constant weight was maintained. Values of LDMC were calculated as the ratio between leaf dry mass and saturated fresh mass $\left(\mathrm{g} \mathrm{g}^{-1}\right)$, and SLA was expressed as the ratio of leaf area to leaf dry mass $\left(\mathrm{cm}^{2} \mathrm{~g}^{-1}\right)$.

Data Analysis: Data were analyzed by one-way analysis of variance (ANOVA) followed by Scheffe's test for comparisons of all treatments against the control. The value of $P<0.05$ was selected as a limit of statistical significance.

\section{RESULTS AND DISCUSSION}

Soil Characteristics: Results of analysis of the soil revealed that the means of $\mathrm{pH}$, Organic Carbon, Total Nitrogen, Electrical Conductivity, Salinity, and OM varied significantly at $(\mathrm{P}<0.05)$ between mangrove soil and garden soil before amendment (Table 1).

Leaf Area and Leaf dry Weight of R. racemosa grown in amended mangrove and garden soil: The leaf area of $R$. racemosa grown in garden soil had a maximum mean value of $14.3 \pm 0.8 \mathrm{~cm}^{2}$ in the bag amended with $\mathrm{RH}$ while the lowest mean value of $9.8 \pm 0.8 \mathrm{~cm}^{2}$ was recorded on the control bag, (Figure 1). In the amended mangrove soil, the maximum leaf area of $17.1 \pm 0.9 \mathrm{~cm}^{2}$ was recorded in the combination amendment $\mathrm{SD}+\mathrm{RH}+\mathrm{NPK}$ while the minimum value of $10.2 \pm 0.9 \mathrm{~cm} 2$ was recorded in the control bag, (figure 1). Within group significant difference was observed between $\mathrm{MS}$ and $\mathrm{MS}+\mathrm{SD} ; \mathrm{MS}$ and $\mathrm{MS}+\mathrm{SD}+\mathrm{RH}+\mathrm{NPK} ; \mathrm{MS}+\mathrm{RH}$ and $\mathrm{MS}+\mathrm{SD}+\mathrm{RH}+\mathrm{NPK} ; \mathrm{MS}+\mathrm{NPK}$ and $\mathrm{MS}+\mathrm{SD}+\mathrm{RH}+$ NPK.

S=Soil, S + SD = Soil + Saw Dust, S + RH = Soil + Rice Husk. S + $\mathrm{SD}+\mathrm{RH}+\mathrm{NPK}=$ Soil + Saw dust + Rice husk + NPK
Table 1: Physicochemical Properties of the different soils before planting

\begin{tabular}{|c|c|c|}
\hline Parameter & Mangrove soil & Garden soil \\
\hline Soil texture & Silty Loam & Clayey \\
\hline 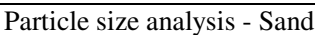 & 15.54 & 27.83 \\
\hline Silt & 84.80 & 11.63 \\
\hline Clay & 0.0 & 60.53 \\
\hline $\mathrm{pH}$ & 3.58 & 6.22 \\
\hline Conductivity $\mu \mathrm{S} / \mathrm{cm}$ & 1685 & 20.9 \\
\hline Salinity (ppm) & 909 & 19.5 \\
\hline Organic matter content $(\%)$ & 29.79 & 3.27 \\
\hline Moisture content (\%) & 23.53 & 14.40 \\
\hline Total N (ppm) & 1.80 & 0.41 \\
\hline Total P (ppm) & 0.68 & 2.54 \\
\hline Total Organic Carbon (\%) & 17.3 & 1.89 \\
\hline
\end{tabular}

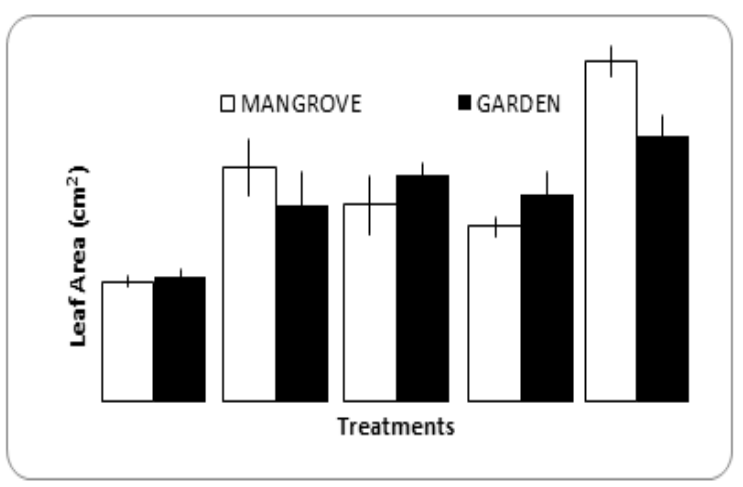

Fig 1: Leaf area of R. racemose grown in amended mangrove and garden soil

The leaf dry weight (LDW) of Rhizophora racemosa recorded a maximum value of $0.181 \pm 0.02 \mathrm{~g}$ in the garden soil treatment amended with NPK while the lowest value of $0.103 \pm 0.008 \mathrm{~g}$ was recorded in the control (GS), (figure 2). There was a significant difference at $\mathrm{p}=0.05$ of leaf dry weight within the garden soils treatment. In the amended mangrove soils, maximum LDW value of $0.222 \pm 0.015 \mathrm{~g}$ was recorded in the combination treatment (SD+RH+NPK), While the minimum value of $0.092 \pm$ $0.004 \mathrm{~g}$ was recorded in control (MS). Specifically, significant difference was observed within the following amendment, MS and MS + NPK; MS and $\mathrm{MS}+\mathrm{SD}+\mathrm{RH}+\mathrm{NPK} ; \mathrm{MS}+\mathrm{SD}$ and $\mathrm{MS}+\mathrm{RH}$ and $\mathrm{MS}+\mathrm{SD}+\mathrm{RH}+\mathrm{NPK}$ respectively.

Specific Leaf Area (SLA) and Leaf Dry Matter Content (LDMC) for Rhizophora racemosa grown in amended mangrove and garden soil: Mean specific leaf area (SLA) and leaf dry matter content (LDMC) were not significantly different $(\mathrm{p}=0.05)$ between the mangrove plants grown in the two types of soil (Figure 3 and 4). Maximum SLA in the mangrove soil amended was observed in the set amended with SD (143.7 \pm $19.3 \mathrm{~cm}^{2} \mathrm{~g}^{-1}$ ) while in the garden soil the maximum value of $150.56 \pm 14.96 \mathrm{~cm}^{2} \mathrm{~g}^{-1}$ was observed in the set amended with GS+SD+RH+NPK. The lowest SLA values for both soil types was $75.5 \pm 5.39 \mathrm{~cm}^{2} \mathrm{~g}^{-1}$ and 
$80.5 \pm 17.7 \mathrm{~cm}^{2} \mathrm{~g}^{-1}$ for the mangrove and garden soil respectively and was observed in the set amended with NPK respectively; (figure 3).

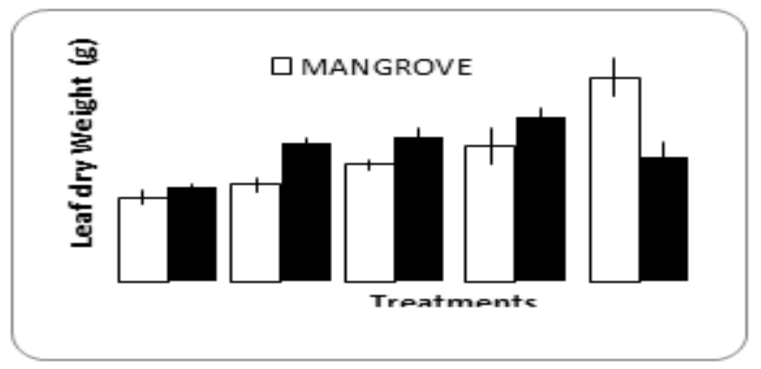

Fig 2: Leaf dry weight of R. racemosa grown in amended mangrove and garden soil

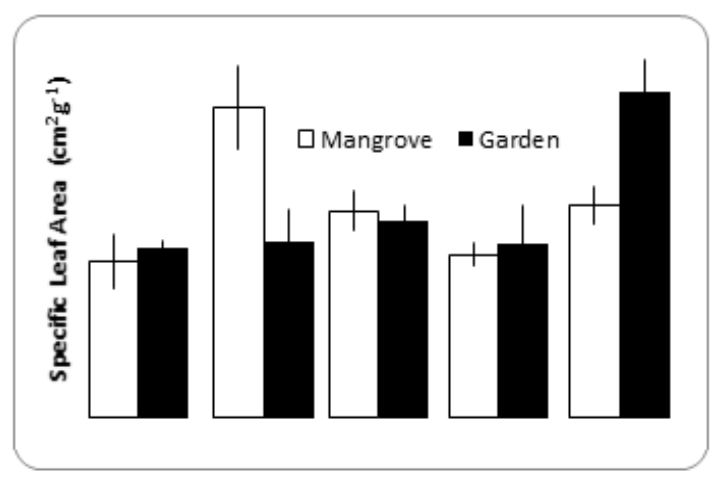

Fig 3.0: Mean SLA of $R$. racemosa grown on amended mangrove and garden soil

LDMC varied from $0.224 \pm 0.012 \mathrm{~g} \mathrm{~g}^{-1}(\mathrm{MS}+\mathrm{SD})$ to $0.271 \pm 0.013 \mathrm{~g} \mathrm{~g}^{-1}(\mathrm{~S}+\mathrm{SD}+\mathrm{RH}+\mathrm{NPK})$. Within the amended mangrove soils there was no significant difference in $\mathrm{LDMC}$ values at $\mathrm{P}<0.05$ for the various amendments. In the garden soil, the minimum LDMC value of $0.256 \pm 0.004 \mathrm{~g} \mathrm{~g}^{-1}$ was recorded in control (GS) while the maximum value of $0.355 \pm 0.041 \mathrm{~g} \mathrm{~g}^{-1}$ was observed in the garden soil amended with NPK (Figure 4). The uniqueness of mangroves habitat makes salinity an important factor restraining propagule germination, its growth and reproduction. Many studies have highlighted the negative effects of salinity on mangroves establishment, growth and development. Such negative relationship as seedling emergence rate and salt content of Avicennia marina (Patel et al., 2010) delay in root initiation of Acanthus ilicifolius (Chen and Ye, 2014) and reduction in final seedling establishment rates of Aegiceras corniculatum besides, (Medina and Francisco, 1997) who have reported considerable decreases in leaf number and area of Avicennia. germinans with increase soil salinity. This study showed that the leaf area of Rhizophara racemosa in the amended garden soil treatments showed no significant differences. However, in the amended mangrove soil, the highest mean value of $17.1 \pm 0.9 \mathrm{~cm}^{2}$ was recorded in the $\mathrm{SD}+\mathrm{RH}+\mathrm{NPK}$ plot and this was significantly different from the mean value of the control plot. The low leaf area as recorded in the control set relative to other amendments of the mangrove soil is an indication of salinity stress. Parida and Das, (2005) have reported a reduction in leaf size of Rhizophora mucronata, Rhizophora apiculata grown in medium saline soil with consequent production of smaller leaves as an adaptation to reduce transpirational loss.

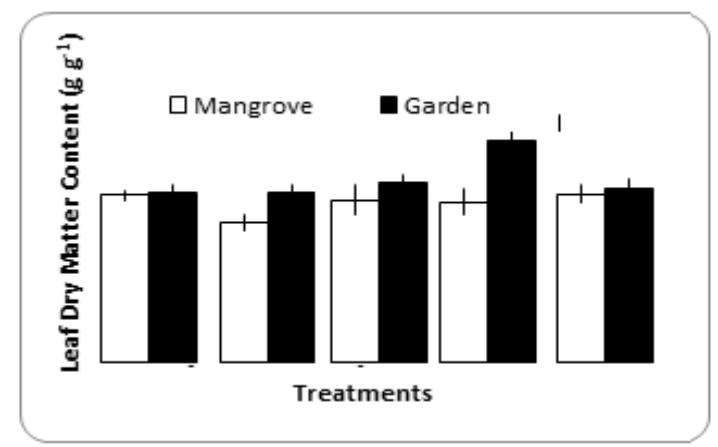

Fig 4: Mean LDMC of R. racemosa grown on amended mangrove and garden soil

Mean values of Leaf dry weight in both the garden and mangrove soil treatment were higher in the amended sets relative to the control. Responses to soil salinity during the early growth of mangrove seedlings have been reported as an important determinant of survival. Specifically, Bruguiera. sexangula exhibited a $45 \%$ reduction of its dry mass under medium saline soil when compared with low salinity conditions after three months of growth (Chen and Ye, 2014) and the report further suggested that growth and development may also be likely impaired at the exhaustion of the initial food reserves in the propagule. The high Leaf dry weight observed in amended mangrove and garden soil may be attributed to the influence of the nutrients in the amendment. Reports of Chen and Ye, (2014) attest to increase in biomass (leaf, shoot, branch growth) of several species of mangrove as Rhizophora mangle Avicennia. germinans Ceriops tagalet on nutrient addition. This is in agreement with the report of (Bhardwaj, 2014) that a good growing media would provide excellent anchorage, serve as nutrient and water repository among others with a consequential positive influence on seedling re-establishment in the field and productivity.

Various reports as Shipley and $\mathrm{Vu}$ (2002) have revealed that SLA is a reflection of previously stored resources and hence plant species with high SLA displays high productivity, and as well do better in resource-rich environments while plant species with low SLA do better in resource-poor environments 
where retention of captured resources is a higher priority. Specific leaf area being a characteristic of the leafiness of a plant recorded an overall highest value in the garden soil amended with SD+RH+NPK combined. This high Specific leaf area may be attributed to the optimal growth condition in terms of nutrient and very low salinity in the amended garden soil as against the high saline soil of the mangrove soil. Evidence have shown that mangroves develops luxuriantly in lower salinities (Tahira et al., 2015) as mangroves in high salinity environment spend more energy to maintain water balance and ion concentration rather than for primary production and growth (Clough, 1984). This is in agreement with the findings of the present study. The differences in the SLA of within garden soil amended soil may be attributed to rate and availability of nutrients in the amendment. In the amended mangrove soil the highest SLA value was observed in the plot amended with SD, however this may have resulted from the liming effect of the organic residue of saw dust as (Haynes and Mokolobate, 2001) has observed liming effect of organic manure such as sawdust. The highest value for LMDC of Rhizophora racemosa was recorded in the amended garden soil when compared to amended mangrove soil. This corroborates the findings, of (Yong et al., 2005) that high salinities reduces biomass, denaturing of terminal buds in Rhizophora mangle seedlings and as well the report of (Medina and Francisco, 1997) that elevated salinities causes reduction in leaf area and decrease in the total Nitrogen, Potassium and Phosphorus minerals of mangrove species. The high saline mangrove soil used in our research may be responsible for the low values of leaf characteristics of the propagules as its early growth and development were hampered by the salinity stress.

Conclusion: The study has demonstrated that the effects of salinity besides other environmental stressors on the mangrove plants specifically in the Niger delta region which is plagued with increasing sea rise level and the consequent high salinity content. Thus the amendment of garden soil with rice husk, saw dust and NPK as lone treatment or in combination may result in growth performance of the mangrove Rhizophora racemosa; it is thus recommended that the mangrove species can be successfully established and raised in amended garden soil for restoration purposes.

\section{REFERENCES}

Akonye, LA; Nwauzoma, B (2003) Growth Measurement in Plants IN: Onyeike, EN; Osuji, JO (Eds) Research Techniques in Biological and Chemical Sciences. Wetra Publishers. Lagos.
Basyuni, M; Nuryawan A; Yunasfi, L; Putri AP; Baba, $S$ (2018). Effect of long-term salinity on the growth and biomass of two non-secretors mangrove plants Rhizophora apiculata and Ceriops tagal. Earth and Environmental Science 122 doi :10.1088/1755-1315/122/1/012042

Bhardwaj, RL (2014). Effect of growing media on seed germination and seedling growth of papaya CV. 'Red lady'. African Journal of Plant Science 8 (4) 178 - 184

Cavalcanti, VF; Andrade, ACS; Soares, MLG (2007) Germination of Avicennia schaueriana and Laguncularia racemosa from Two Physiographic Types of Mangrove Forest. Aquatic Botany, 86, 285-290.

Chen, Y; Ye, Y (2014) Effects of Salinity and Nutrient Addition on Mangrove Excoecaria agallocha. PLoS ONE 9 4: e93337. - doi: 10.1371/journal. pone.0093337

Clough, BF (1984) Growth and salt balance of the mangrove Avicennia marina (Forsk.) Vierh. and Rhizophora stylosa Griff. in relation to salinity. Aust J Plant Physiology 11: 419-430

Daniel, A; Edward, FLW (2013). Variability in mangrove change estimates and implications for the assessment of ecosystem service provision. Global Ecology and Biogeography, http://wileyonlinelibrary.com/journal/geb

Dike, BU; Nwachukwu, BA (2003). Analysis of Nigeria Hydrometrological Data.

Nig. J. Technol. 22(1) 28-32

Díaz, S; Hodgson, JH; Thompson, K; Cabido,M; Cornelissen, JHC; Jalili, A (2004). The plant traits that drive ecosystems: evidence from three continents. Journal of Vegetation Science. 15:295-304.

Donato, DC; Kauffman, JB; Murdiyarso, D; Kurnianto, S;,Stidham, M; Kanninen, M (2011) Mangroves among the most carbon-rich forests in the tropics. Nature Geoscience, 4, 293-297.

Doyle, TW (2003). Effects of Hydrology on Red Mangrove Recruits. USGS Fact Sheet FS-02903, U.S. Geological Survey March 2003

Duke, NC; Allen, JA (2006) Rhizophora mangle, R. samoensis, R. racemosa, R. $\times$ harrisonii (Atlantic- 
East Pacific Red Mangrove). Species Profiles for Pacific Island Agroforestry, 10, 1-18.

Garnier, E; Shipley B; Roumet, C; Laurent, G (2001). A standardized protocol for the determination of specific leaf area and leaf dry matter content. Functional Ecology.15:688-695.

Haynes, RJ; Mokolobate, MS (2001) Amelioration of Al Toxicity and P Deficiency in acid Soils by Additions of Organic Residues: A Critical Review of the Phenomenon and the Mechanisms Involved. Nutr. Cycling Agroecosyst, 59: 47-63

Hogarth, PJ (1999). The biology of mangroves and seagrasses. Oxford University Press.

Lucas, R; Robelo, L; Fatoyinbo, L; Rosenqvist, A; Itoh, T; Shimada, M (2014) Contribution of Lband SAR to Systematic Global Mangrove Monitoring. Mar. Freshwater Res. 2014.

Medina, E; Francisco M (1997) Osmolality and $\delta^{13} \mathrm{C}$ of leaf tissue of mangrove species from environments of contrasting rainfall and salinity. Estuarine Coastal and Shelf Sci. 45: 337-344.

Nelson, DW; Sommers, LE (1996). Total carbon, organic carbon, and organic matter. Sparks DL, editor Methods of soil analysis Part 3: Chemical methods. Madison: Soil Sci. Soc. Amer. 9611010.

Niger Delta Environmental Survey (NDES). (2000). Ecological zonation and habitat classification. $2^{\text {nd }}$ Phase Report 2, Vol.1: 1-66.

Pandey, SK; Singh, H (2011). A Simple, CostEffective Method for Leaf Area Estimation. $J$. Botany Article ID 658240, 6
Patel NT; Gupta A; Pandey; AN (2010) Salinity tolerance of Avicennia marina (Forssk.) Vierh. from Gujarat coasts of India. Aquat Bot 93: 9-16.

Research Planning Institute (RPI). (1985).Environmental baseline studies for establishment of control criteria and standards against petroleum related pollution in Nigeria. RPI/84/4/15-7.

Shipley, B; Vu, T-T. (2002). Dry matter content as a measure of dry matter concentration in plants and their parts. New Phytology 153: 359-364.

Tahira, N; Nazima, B; Roomina, M; Noshin, I (2015) Effects of Siltation, Temperature and Salinity on Mangrove Plants Euro. Acad. Res. II: 11

Twilley, R.R; Chen, R. (1998). A water budget and hydrology model of a basin mangrove forest in Rookery Bay, Florida. Mar. Freshwater Res. 49: 309-323.

Uko, ED; Tamunobereton-Ari, I (2013) Variability of Climatic Parameters in Port Harcourt, Nigeria. J. Emerging Trends in Engineering and Appl. Sci. (JETEAS) 4 5: 727-730

Wright, IJ; Westoby, M (2003). Nutrient concentration, resorption and lifespan: leaf traits of Australian sclerophyll species. Functional Ecology 17, 10-19

Yong Ye; Nora FT; Chang, YL; Yuk-Shan, W (2005). Effects of salinity on germination, seedling growth and physiology of three salt-secreting mangrove species. Aquatic Botany 83,193 -205 